\title{
Rancang Bangun Alat Pengukur Gelombang Permukaan Laut Presisi Tinggi (A Prototype Design)
}

\author{
Okol Sri Suharyo \\ Sekolah Tinggi Teknologi Angkatan Laut Surabaya \\ E-mail: okolsrisuharyo@sttal.ac.id
}

\begin{abstract}
Abstrak
Gelombang permukaan laut adalah salah satu fenomena yang sangat kompleks dan mudah berubah dibandingkan dengan arus dan pasang surut, sehingga untuk memahami secara menyeluruh tentang perilaku dan karakteristik gelombang permukaan laut merupakan hal yang sulit. Gelombang tersebut pada hakekatnya adalah gelombang acak yang terbentuk karena berbagai macam jenis gelombang dengan frekuensi tertentu yang bersuperposisi satu sama lainnya. Sumber pembangkit gelombang tersebut terutama adalah angin, sehingga sering disebut dengan Gelombang Angin (Wind Waves). Secara teoritis, terdapat metode analisis gelombang berdasarkan ketersediaan data dalam suatu perairan, yaitu metode Analisa Gelombang Kurun Waktu Pendek (Short Term Wave Analysis (STWA)) dan metode Analisa Gelombang Kurun Waktu Panjang (Long Term Wave Analysis (LTWA)). Metode STWA adalah melakukan analisa berdasar data gelombang yang pendek, sedangkan metode LTWA dilakukan dengan menggunakan data dalam kurun waktu panjang dan umumnya lebih dari 1 (satu) tahun. Terutama LTWA sangat dibutuhkan untuk mengetahui gelombang yang dipengaruhi oleh musim di Indonesia. Sampai saat ini belum ada data panjang atau kajian gelombang di Indonesia yang menggunakan data panjang karena keterbatasan data detail yang sangat dibutuhkan untuk melakukan analisis tersebut. Untuk mendapatkan data gelombang acak dari berbagai sumber pembangkit gelombang memerlukan alat yang memadai untuk memperoleh datanya. Pada dasarnya ada beberapa jenis alat yang dapat dipergunakan baik di dalam dan di luar untuk memenuhi kebutuhan data tersebut, namun umumnya memerlukan biaya yang tidak sedikit. Sering terjadi bahwa alat yang diperlukan tidaklah sekompleks keperluan untuk pengadaan suatu penelitian yang sederhana, hanya membutuhkan satu atau dua parameter, misalkan untuk mencari data gelombang diperlukan parameter data berupa tinggi air dan waktu, oleh karena itu desain dan alat yang sederhana namun memenuhi kebutuhan untuk pemenuhan data sangatlah membantu dan dapat mengurangi beban biaya penelitian. Pada riset ini diusulkan desain dan pembuatan alat dan sistem gelombang presisi tinggi, dimana diharapkan dalam hitungan detik dapat diperoleh beberapa data gelombang berupa tinggi permukaan air dan waktu pengambilan datanya secara real time dan up to date.
\end{abstract}

Kata Kunci: Alat Ukur, Tinggi Gelombang, Permukaan Laut

\section{PENDAhuluan}

Keselamatan, keamanan, dan kenyamanan adalah hal yang selalu dijaga bagi semua kapal pada umumnya; tetapi kondisi cuaca laut tidak dirasakan sama bagi setiap kapal, melainkan bergantung kepada besar dan desain serta perlengkapan masing-masing kapal. Namun demikian keselamatan adalah yang paling diutamakan bagi semua kapal. Fungsi utama dari informasi meteorologi bagi pelayaran adalah memberi petunjuk pemilihan jalan agar dapat berlayar dengan aman, nyaman, selamat sampai tujuan, dan tepat waktu. Informasi angin dan gelombang perlu memuat keterangan mengenai lokasinya, keberadaanya dan atau yang diprakirakan akan adanya. Prakiraan dan gawar (warning) gelombang hendaknya memberi gambaran mengenai daerah di mana adanya atau akan adanya, tingginya dan batas maksimumnya, arahnya, dan periode gelombangnya.

Gelombang permukaan laut adalah salah satu fenomena yang sangat kompleks dan mudah berubah dibandingkan dengan arus dan pasang surut, sehingga untuk memahami secara menyeluruh tentang perilaku dan karakteristik gelombang permukaan laut merupakan hal yang 
sulit. Gelombang tersebut pada hakekatnya adalah gelombang acak yang terbentuk karena berbagai macam jenis gelombang dengan frekuensi tertentu yang bersuperposisi satu sama lainnya. Sumber pembangkit gelombang tersebut terutama adalah angin, sehingga sering disebut dengan Gelombang Angin (Wind Waves).

Untuk mendapatkan data gelombang acak dari berbagai sumber pembangkit gelombang memerlukan alat yang memadai untuk memperoleh datanya. Pada dasarnya ada beberapa jenis alat yang dapat dipergunakan baik di dalam dan di luar untuk memenuhi kebutuhan data tersebut, namun umumnya memerlukan biaya yang tidak sedikit. Sering terjadi bahwa alat yang diperlukan tidaklah sekompleks keperluan untuk pengadaan suatu penelitian yang sederhana, hanya membutuhkan satu atau dua parameter, misalkan untuk mencari data gelombang diperlukan parameter data berupa tinggi air dan waktu, oleh karena itu desain dan alat yang sederhana namun memenuhi kebutuhan untuk pemenuhan data sangatlah membantu dan dapat mengurangi beban biaya penelitian.

Pada penelitian ini diusulkan desain dan pembuatan alat yang mempunyai konsep berbeda dan lebih baik, efisien dan efektif dengan alat alat ukur sebelumnya, dengan pengukuran tinggi gelombang permukaan laut yang efisien, efektif dan real time, dimana diharapkan dalam hitungan detik dapat diperoleh beberapa data gelombang berupa tinggi permukaan air dan waktu pengambilan datanya secara real time dengan presisi dan ketepatan pengukuran yang baik.

\section{STUDI LITERATUR}

Deskripsi tentang sebuah gelombang hingga kini masih belum jelas dan akurat, oleh karena permukaan laut merupakan suatu bidang yang kompleks dengan pola yang selalu berubah dan tidak stabil (Garrison, 1993). Gelombang merupakan fenomena alam penaikan dan penurunan air secara periodik dan dapat dijumpai di semua tempat di seluruh dunia. Gross (1993) mendefinisikan gelombang sebagai gangguan yang terjadi di permukaan air. Sedangkan Pond (1978) mendefenisikan gelombang sebagai sesuatu yang terjadi secara periodik terutama gelombang yang disebabkan oleh adanya peristiwa pasang surut.

Berdasarkan kedalaman, gelombang yang bergerak mendekati pantai dapat dibagi menjadi dua bagian yaitu gelombang laut dalam dan permukaan. Gelombang laut dalam adalah gelombang yang dibentuk dan dibangun dari bawah kepermukaan. Sedangkan gelombang permukaan merupakan gelombang yang terjadi antara batas dua media seperti batas air dan udara (Gross, 1993).

Gelombang permukaan terjadi karena adanya pengaruh angin. Peristiwa ini merupakan peristiwa pemindahan energi angin menjadi energi gelombang di permukaan laut dan gelombang ini sendiri akan meneruskan energinya ke molekul air. Gelombang akan menimbulkan riak dipermukaan air dan akhirnya dapat berubah menjadi gelombang yang besar. Gelombang yang bergerak dari zona laut lepas hingga tiba di zona dekat pantai (nearshore beach) akan melewati beberapa zona gelombang, yaitu zona laut dalam (deep water zone), zona refraksi (refraction zone), zona pecah gelombang (surf zone) dan zona pangadukan gelombang (swash zone) (PondPickard, 1978).

Gelombang laut memiliki parameter yaitu periode gelombang, panjang gelombang, tinggi gelombang dan cepat rambat gelombang. Periode gelombang (T) adalah waktu tempuh di antara dua puncak atau dua lembah gelombang secara berurutan pada titik yang tetap (satuan detik). Panjang gelombang (L) adalah jarak horizontal antara dua puncak atau dua lembah yang berurutan (satuan meter). Tinggi gelombang $(\mathrm{H})$ adalah jarak vertikal antara puncak gelombang dan lembah gelombang (satuan meter). Cepat rambat gelombang (C) adalah kecepatan tempuh perjalanan 
suatu gelombang, yang dapat diperoleh dengan pembagian panjang gelombang (L) dengan periode gelombang $(\mathrm{T})$ atau $\mathrm{C}=\mathrm{L} / \mathrm{T}$.

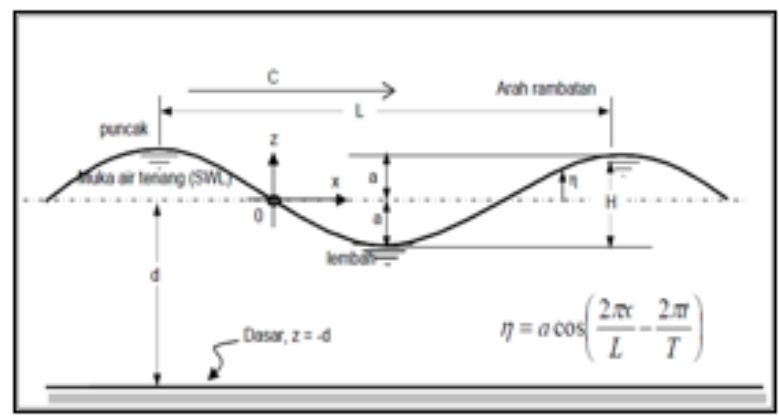

Gambar 15. Parameter Gelombang

\section{METODOLOGI}

Adapun metode penelitian yang dimaksud adalah tahapan-tahapan kegiatan yang dilaksanakan dalam perancangan dan pembuatan desain alat dan sistem pencatat gelombang permukaan laut presisi tinggi sesuai diagram alir di bawah ini:

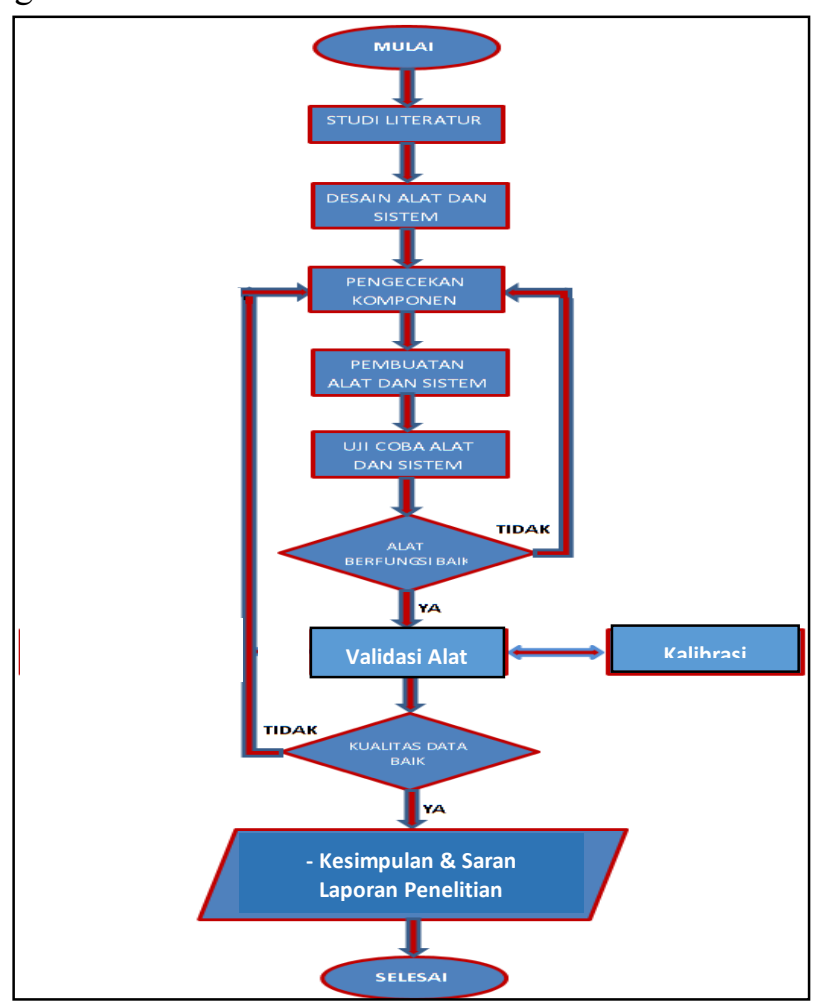

Gambar 16. Diagram Alir Metode Penelitian

\section{DESAIN DAN RANCANGAN ALAT}

Desain dan rancangan alat pengukur gelombang permukaan laut ditampilkan dalam gambar di bawah ini: 


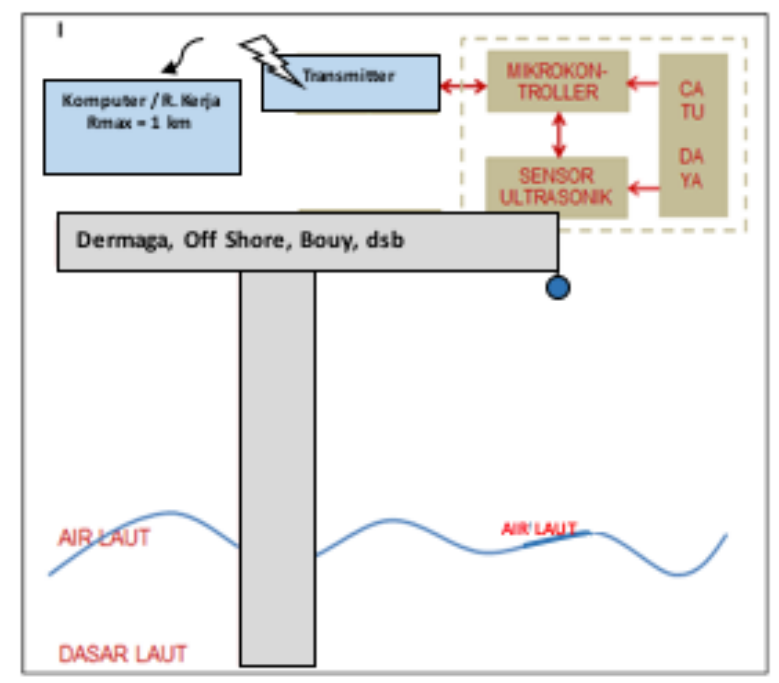

Gambar 17. Desain dan Rancangan Alat

Alat pengukur tinggi gelombang permukaan laut dipasang di atas permukaan air laut pada dermaga, bangunan lepas pantai atau mooring bouy seperti pada Gambar 3 di atas. Alat tersebut di hubungkan dengan sensor ultrasonik dan mikrokontroller untuk menerima data ukuran ketinggian gelombang secara real time dan nirkabel, yang kemudian bisa ditampikan pada display lapotop/komputer kerja di ruangan atau kantor. Catu daya atau aki diperlukan sebagai penyedia energi atau power untuk sensor ultrasonik dan mikrokontroller.

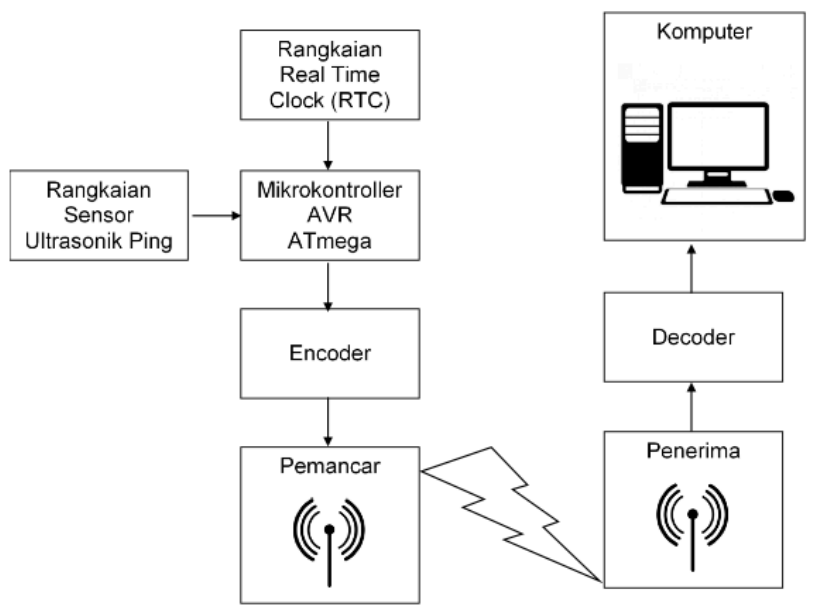

Gambar 18. Diagram Desain Alat

Kemampuan jarak jangkau yang dirancang pada alat ini adalah mampu mengirimkan data secara real time ketinggian gelombang permukaan laut paling jauh $1 \mathrm{Km}$, dari posisi sensor dan pemancar alat di dermaga / off shore / mooring bouy ke posisi penerima atau komputer kerja user di kantor. Beberapa kegunaan dasar alat ini selain untuk memonitor tinggi gelombang permukaan laut secara real time, adalah juga digunakan untuk keperluan data pada perencanaan ketinggian dermaga Pangkalan TNI AL, break water dan perencanaan bangunan off shore lepas pantai.

\section{DEVELOPING ALAT DAN SISTEM}

Alat pengukur ketinggian gelombang permukaan laut ini terdiri dari beberapa komponen utama sebagai berikut: 
a. Laptop / Notebook Acer: Aspire V5-132-10192G50nbb, Intel Processor 1019Y 1.0GHz, 2Mb L3 Cache Memory 2 GB DDR3 Harddisk 500GB HDD

b. Sensor Ultrasonik: SRF10 Ultrasonic Range Finder

c. Mikrokontroller AVR ATmega: AT24C256 EEPROM Module

d. Arduino Due R3 SAM3X8E 32-bit ARM Cortex-M Compatible Board Module.

e. LCD HD44780

f. Radio Link

g. Support Component (accu, connector, cable)

Komponen-komponen tersebut diatas dicek dalam hal ketersediaan bahan di lapangan, performance tiap-tiap komponen, serta bagaimana sistem internal konfigurasi panyambungan antar komponen.

Langkah berikutnya adalah pembangunan dan perakitan alat yaitu berupa developing perangkat keras (hardware), developing perangkat lunak (software) dan pembuatan interface atau tampilan program perangkat keras dan lunak, dengan perincian kegiatan sebagai berikut:

a. Perancangan dan Pembuatan Perangkat Keras (Hardware)

Komponen-komponen yang digunakan dalam pembuatan perangkat keras antara lain Mikrokontroller ARDUINO UNO, RTC, Data Logging, RF 433 dan LCD.

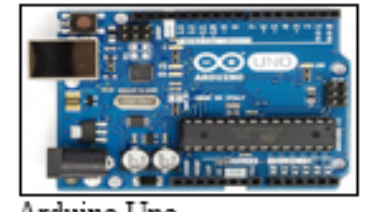

Arduino Uno

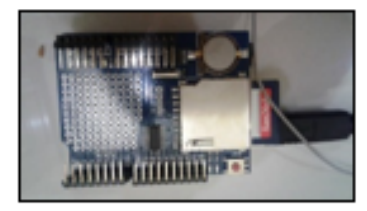

RTC dan Data Logging

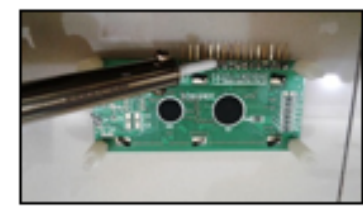

LCD Display

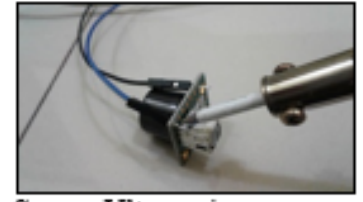

Sensor Ultrasonic
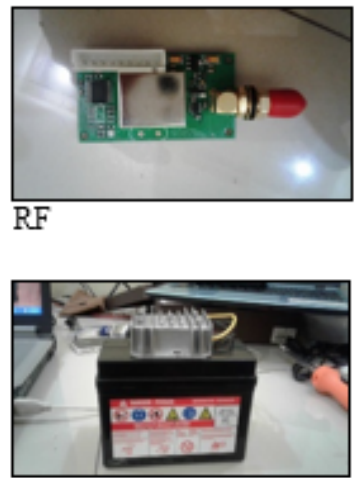

Catu Daya

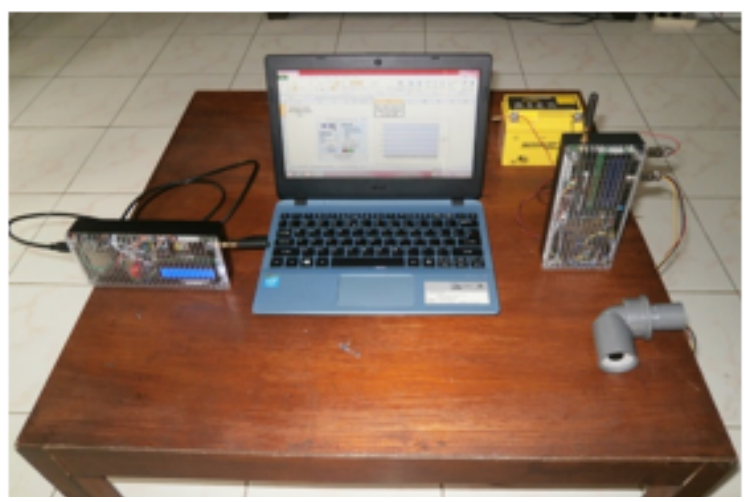

Gambar 19. Developing Perangkat Keras 
b. Perancangan perangkat lunak (software)

Perangkat lunak yang digunakan dalam penelitian ini adalah penyusunan software program ARDUINO 1.5.2 dan PLX DAQ dengan Bahasa pemrograman Bahasa C yang diakuisisikan pada format program data excel.

c. Interface Perangkat Keras dan LunakPerangkat keras dan lunak dibuat, dikoneksikan sedemikian hingga dapat mengukur, menyimpan serta menampilkan ketinggian gelombang air laut, baik di layar LCD ataupun monitor komputer kerja secara real time dan ketepatan hasil ukur yang baik.

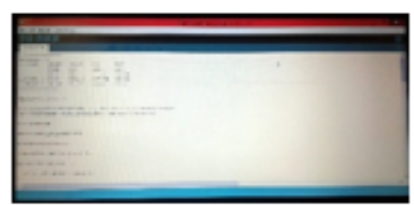

Sketch Transmitter

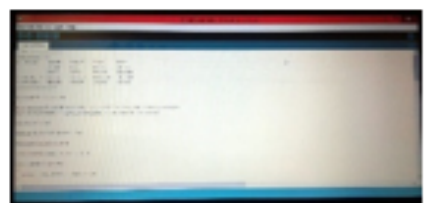

Sketch Reciever

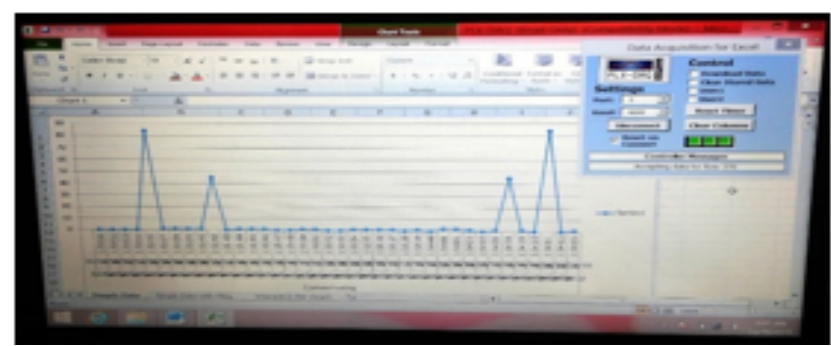

Gambar 20. Interface Data Real Time Excel

\section{VALIDASI DAN KALIBRASI}

Pengujian atau validasi sistem alat keseluruhan dilakukan untuk mengetahui kinerja alat secara keseluruhan. Pengujian dilakukan di Laboratorium Flume FTK ITS. Pengujian dilakukan dengan 3 (tiga) Percobaaan pada bak ukur gelombang air seperti pada Gambar 7. Penambahan gelombang air yang menyebabkan tinggi permukaan air bertambah dilakukan dengan mengisi bak air menggunakan mesin pompa air. Proses pengambilan data ketinggian gelombang air dilakukan dengan 2 cara yaitu:

(1) Pembacaan meteran yang ditempelkan pada bak ukur secara aktual yang disebut dengan Data Aktual,

(2) Pembacaan pada pengukuran dengan alat rancangan penelitian ini, yang disebut bacaan Data Alat.

Dimana hasil keduanya akan dibandingkan untuk kalibrasi alat. Secara kuantitatif, validasi alat pengukur tinggi gelombang permukaan air dilakukan dengan metode Black Box (Barlas, 2006). Metode Black Box dilakukan dengan membandingkan rata-rata nilai pada data aktual (pengukuran langsung dengan meteran) yang kemudian dibandingkan dengan rata-rata nilai pada data hasil pengukuran alat rancangan. Untuk menemukan rata-rata error yang terjadi dengan menggunakan persamaan berikut ini:

$\mathrm{E}=|(\mathrm{S}-\mathrm{A}) / \mathrm{A}|$

dengan:

A = Data Aktual (pengukuran langsung dengan meteran)

$\mathrm{S}=$ Data Alat (pengukuran dengan alat rancangan)

$\mathrm{E}=$ Variansi error antara data aktual dan data alat

Dimana jika $\mathrm{E}<0,1$ atau $10 \%$ maka model alat Valid 


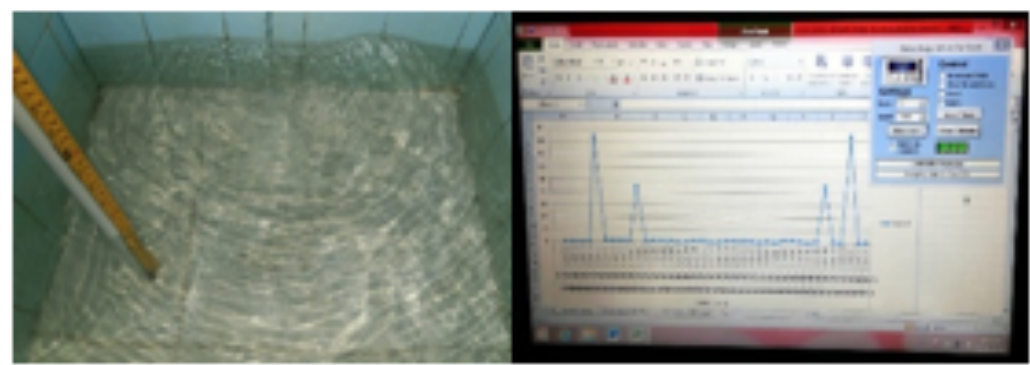

Gambar 21. Proses Kalibrasi Alat

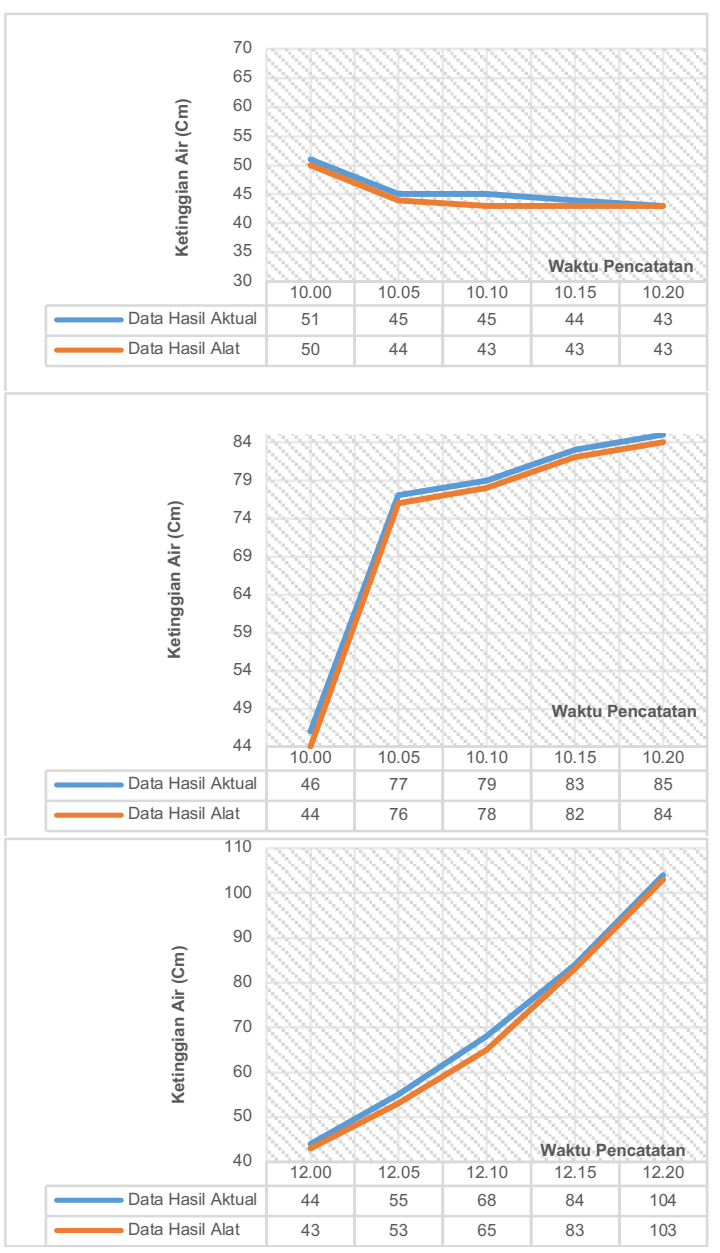

Gambar 22. Grafik Kalibrasi Percobaan Lab. I, II, III

Tabel 1. Perhitungan Error antara Data Aktual dan Data Alat pada Pengujian Laboratorium

\begin{tabular}{|l|l|l|l|}
\hline \multirow{2}{*}{ Time } & Percobaan I & $\begin{array}{l}\text { Data Aktual } \\
(\mathrm{cm})\end{array}$ \\
\cline { 2 - 4 } & $\begin{array}{l}\text { Bacaan Data Alat } \\
(\mathrm{cm})\end{array}$ & 51 & Error \\
\hline 10.00 & 50 & 45 & 0,0196 \\
\hline 10.05 & 44 & 45 & 0,0222 \\
\hline 10.10 & 43 & 44 & 0,0444 \\
\hline 10.15 & 43 & 43 & 0,0227 \\
\hline 10.20 & 42 & 0,0232 \\
\hline Rata-rata Error & $\mathbf{0 , 0 2 6 4}$ \\
\hline \multirow{3}{*}{ Time } & Percobaan II & \\
\cline { 2 - 4 } & $\begin{array}{l}\text { Bacaan Data Alat } \\
(\mathrm{cm})\end{array}$ & $\begin{array}{l}\text { Data Aktual } \\
(\mathrm{cm})\end{array}$ & Error \\
\hline 11.00 & 45 & 46 & 0,0217 \\
\hline 11.05 & 76 & 77 & 0,0129 \\
\hline 11.10 & 78 & 79 & 0,0126 \\
\hline
\end{tabular}




\begin{tabular}{|l|l|l|l|}
\hline 11.15 & 82 & 83 & 0,0120 \\
\hline 11.20 & 84 & 85 & 0,0117 \\
\hline \multicolumn{3}{|l|}{ Rata-rata Error } & $\mathbf{0 , 0 1 4 2}$ \\
\hline \multirow{2}{*}{ Time } & \multicolumn{2}{|l|}{ Percobaan III } & \\
\cline { 2 - 5 } & $\begin{array}{l}\text { Bacaan Data Alat } \\
\mathrm{cm})\end{array}$ & $\begin{array}{l}\text { Data Aktual } \\
(\mathrm{cm})\end{array}$ & Error \\
\hline 11.00 & 43 & 44 & 0,0134 \\
\hline 11.05 & 53 & 55 & 0,0144 \\
\hline 11.10 & 66 & 68 & 0,0102 \\
\hline 11.15 & 83 & 84 & 0,0094 \\
\hline 11.20 & 103 & 104 & 0,0104 \\
\hline \multicolumn{2}{|l|}{} & $\mathbf{0 , 0 1 1 6}$ \\
\hline
\end{tabular}

Berdasarkan perhitungan pada Tabel 1 nilai rata-rata error (E) untuk Percobaan I 0,0264, Percobaan II adalah 0,0142, dan Percobaan III adalah 0,0116, dimana semua nilai error ketiga Percobaan tersebut lebih kecil dari 0,10 atau $<10 \%$. Oleh karena itu, model alat dikatakan valid secara kuantitatif.

Dari hasil percobaan di Laboratorium didapat variansi error atau ketidak-akuratan alat paling tinggi sebesar $2.64 \%<10 \%$ (sesuai Percobaan I). Artinya Keakuratan Pengukuran Alat pada percobaan di laboratorium adalah sebesar $97.36 \%$.

Hasil ini menurut Barlas (2006) termasuk dalam katagori alat ukur dengan presisi tinggi, karena batas nilai error atau ketidak-akuratan alat adalah $10 \%$, sehingga model alat dapat dikatakan VALID secara kuantitatif berdasarkan perhitungan dan percobaan ilmiah.

\section{UJI COBA LAPANGAN}

Uji coba alat selanjutnya dilakukan di lapangan, uji coba ini bertujuan untuk mengukur performance dan keakuratan alat ketika dipasang langsung di lapangan dalam hal ini di perairan / laut. Tahapan-tahapan yang harus dlakukan dalam uji coba lapangan ini meliputi:

a. Persiapan Tempat Uji Coba Lapangan

Uji coba lapangan dilaksanakan di laut selat Madura yaitu di dermaga Koarmatim. Persiapan tempat dilakukan untuk menentukan posisi dimana alat tersebut dipasang sehingga dapat dilakukan pengambilan data pengukuran gelombang permukaan laut secara baik dan real time.

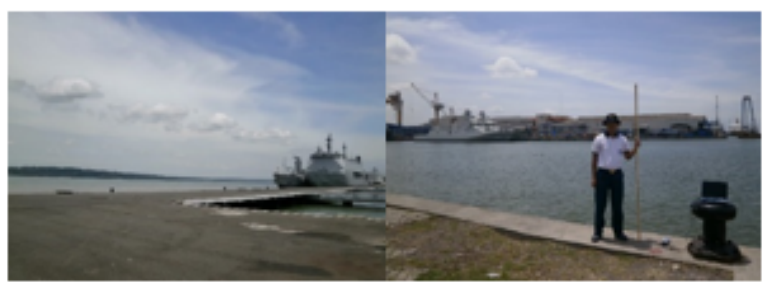

Gambar 23. Persiapan Tempat Uji Coba Lap.

b. Persiapan Alat Rancangan

Persiapan alat rancangan dilakukan dengan tujuan untuk mengecek seluruh komponen dan sistem peralatan rancangan berjalan dengan baik sehingga menghasilkan data pengukuran yang dapat dipertanggungjawabkan secara ilmiah. Hal-hal yang dipersiapkan meliputi sebagai berikut:

- Laptop kerja / notebook, yang telah berisi software program Arduiono 1.5.2 PLX DAQ, yang dapat menampilkan pergerakan ketinggian gelombang permukaan air laut secara real time dan akurat.

- Receiver TX, yang berfungsi untuk menerima sinyal data secara nirkabel dan real time yang 
c. Pelaksanaan Pengambilan Data / Pengukuran Lapangan

Pengambilan data atau pengukuran data di lapangan dilakukan di laut selat Madura tepatnya di dermaga Koarmatim yang dilaksanakan dengan 3 (tiga) kali uji coba. Setiap uji coba dilaksanakan sebanyak 5 kali percobaan pengukuran, sehingga didapatkan 15 data hasil pengukuran. Data hasil pengukuran ini kemudian diolah dan dianalisa untuk mendapatkan koreksi dan nilai keakuratan alat. Cara pengukuran data dilakukan sama dengan di laboratorium yaitu dengan pengambilan data berdasarkan bacaan alat rancangan, yang kemudian dibandingkan dengan bacaan secara data aktual di lapangan dengan meteran.
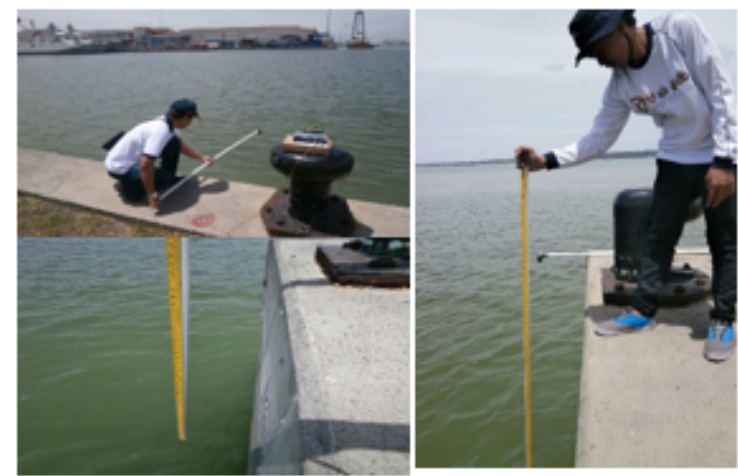

Gambar 24. Pengambilan Data Uji Coba Lapangan

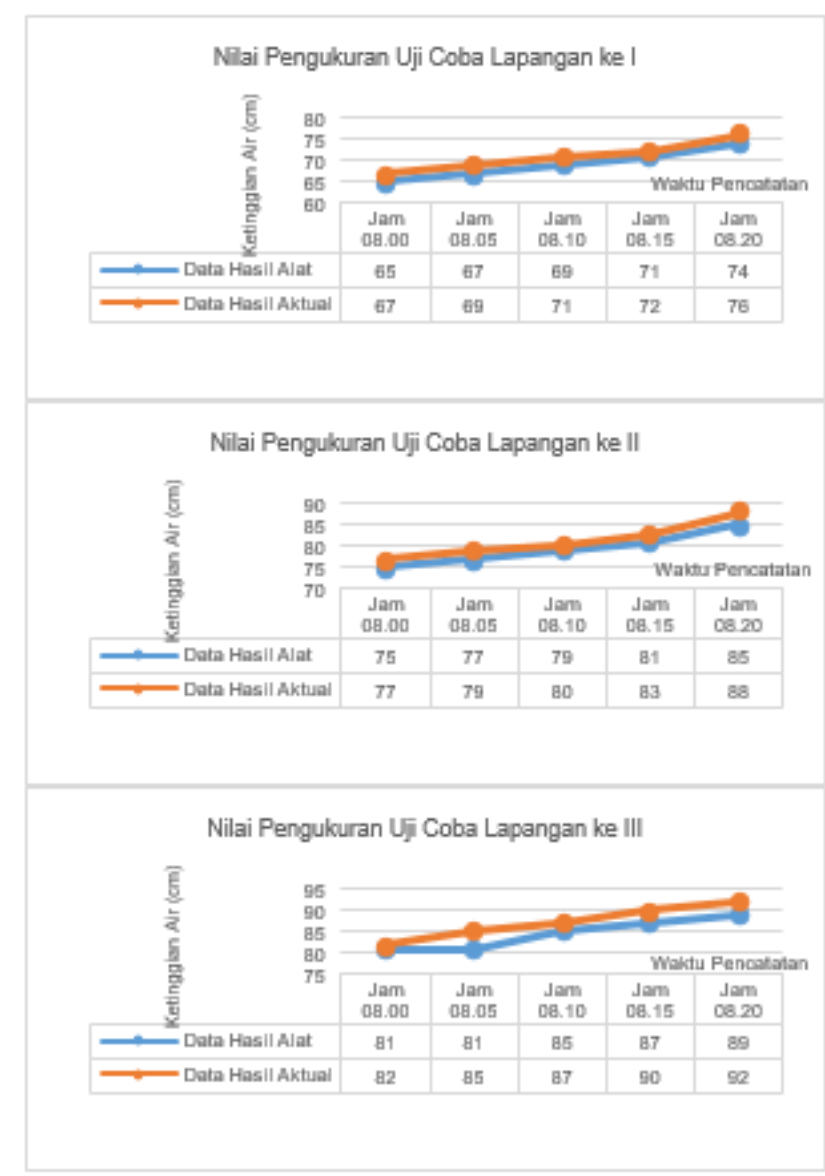

Gambar 25. Grafik Pengukuran Uji Coba Lapangan 
Tabel 2. Perhitungan Error antara Data Aktual dan Data Alat pada Uji Coba Lapangan

\begin{tabular}{|l|l|l|l|}
\hline \multirow{2}{*}{ Time } & \multicolumn{2}{|l|}{ Uji Coba I } & \\
\cline { 2 - 4 } & $\begin{array}{l}\text { Bacaan Data Alat } \\
(\mathrm{cm})\end{array}$ & $\begin{array}{l}\text { Data Aktual } \\
(\mathrm{cm})\end{array}$ & Error \\
\hline 08.00 & 65 & 67 & 0,0298 \\
\hline 08.05 & 67 & 69 & 0,0289 \\
\hline 08.10 & 69 & 71 & 0,0281 \\
\hline 08.15 & 71 & 72 & 0,0138 \\
\hline 08.20 & 74 & 76 & 0,0263 \\
\hline Rata-rata Error & Uji Coba II & $\mathbf{0 , 0 2 5 4}$ \\
\hline \multirow{3}{*}{ Time } & $\begin{array}{l}\text { Bacaan Data Alat } \\
\text { (cm) }\end{array}$ & $\begin{array}{l}\text { Data Aktual } \\
(\mathrm{cm})\end{array}$ & Error \\
\hline 09.00 & 75 & 77 & 0,0260 \\
\hline 09.05 & 77 & 79 & 0,0253 \\
\hline 09.10 & 79 & 90 & 0,1222 \\
\hline 09.15 & 81 & 83 & 0,0241 \\
\hline 09.20 & 85 & 86 & 0,0116 \\
\hline Rata-rata Error & Uji Coba III & $\mathbf{0 , 0 4 1 8}$ \\
\hline \multirow{2}{*}{ Time } & $\begin{array}{l}\text { Bacaan Data Alat } \\
(\mathrm{cm})\end{array}$ & $\begin{array}{l}\text { Data Aktual } \\
(\mathrm{cm})\end{array}$ & Error \\
\hline & 81 & 82 & 0,0122 \\
\hline 10.00 & 83 & 85 & 0,0235 \\
\hline 10.05 & 85 & 87 & 0,0230 \\
\hline 10.10 & 87 & 90 & 0,0333 \\
\hline 10.15 & 89 & 92 & $\mathbf{0 , 0 2 4 9}$ \\
\hline 10.20 & \multicolumn{2}{|l}{} \\
\hline Rata-rata Error & & \\
\hline
\end{tabular}

Berdasarkan perhitungan pada Tabel 2 nilai rata-rata error (E) untuk uji coba lapangan ke I adalah 0,0254, kemudian untuk uji coba lapangan ke II adalah 0,0418, selanjutnya untuk uji coba lapangan ke III adalah 0,0249 dimana semua nilai error ketiga Percobaan tersebut lebih kecil dari 0,10 atau $<10 \%$. Oleh karena itu, model alat dikatakan valid secara kuantitatif.

Sehubungan dengan tujuan penelitian, pengujian ini dilakukan untuk mengukur ketepatan dan keakuratan alat dalam mengukur ketinggian gelombang permukaan air yang menjadi output dari penelitian ini. Dari hasil percobaan di lapangan didapat variansi error atau ketidak-akuratan alat paling tinggi sebesar $4.18 \%<10 \%$ (sesuai Uji coba II). Artinya Keakuratan Pengukuran Alat pada percobaan di lapangan adalah sebesar $95.82 \%$.

Hasil ini menurut Barlas (2006) termasuk dalam katagori alat ukur dengan Presisi tinggi dan kesalahan pengukuran atau error masih dalam batas toleransi, karena batas nilai error atau ketidak-akuratan alat adalah $10 \%$, sehingga model alat dapat dikatakan VALID secara kuantitatif berdasarkan perhitungan dan percobaan ilmiah yang dapat dipertanggung-jawabkan.

\section{KESIMPULAN DAN SARAN}

Dari serangkaian kegiatan penelitian, rancang bangun alat, uji coba laboratorium dan uji coba lapangan yang telah dilaksanakan, maka dapat diambil beberapa kesimpulan dan saran sebagai berikut:

\section{Kesimpulan}

a. Pengukuran gelombang permukaan laut di suatu perairan secara real time dan up to date dapat dilaksanakan dengan melakukan rancang bangun alat hasil penelitian ini. Alat hasil penelitian ini merupakan gabungan antara software program Arduino 1.5.2 PLX DAQ dengan sistem rancangan hardware berupa Laptop/ Notebook Processor 1019Y 1.0GHz, 2Mb L3 Cache Memory 2 GB, Sensor Ultrasonik, Mikrokontroller AVR ATmega, LCD 
HD44780 dan Radio Link. Semua komponen dirancang dan disusun sebagai sistem yang terintegrasi dalam pengukuran gelombang permukaan laut secara real time dan up to date

b. Alat ukur gelombang permukaan laut ini terdiri dari komponen-komponen utama yaitu: Laptop/notebook kerja yang terinstal program Arduino PLX DAQ dan terhubung dengan Receiver RX yang berfungsi sebagai display real time dan up to date gelombang permukaan laut. Receiver menerima sinyal data dengan jarak paling jauh $1 \mathrm{Km}$ dari Transmitter RX yang terhubung dengan ultrasonic sensor yang bisa ditempatkan di dermaga, off shore atau mooring bouy untuk mencatat data ketinggian gelombang permukaan laut secara real time dengan keakuratan data yang baik

c. Hasil uji percobaan di laboratorium pada alat rancangan pengukur gelombang permukaan laut menunjukkan keakuratan data sebesar $97,36 \%$ dan hasil uji coba di lapangan menunjukkan keakuratan data sebesar 95,82 \%. Hasil ini sangat baik dan menunjukkan tingkat Presisi yang tinggi pada alat hasil rancangan

d. Keamanan data lebih terjamin karena data-data yang didapat sebelum ditransfer ke alat Receiver RX telah dienskripsi terlebih dahulu pada alat Transmitter TX sehingga menghasilkan data analog angka yang real time yang selanjutnya masuk ke dalam software program Arduino untuk diakuisisi menjadi tampilan interface yang real time / up to date.

e. Alat yang telah dibuat sangat mampu meminimalisasi peran manusia / operator dalam pengumpulan, pengolahan maupun dan penyajian data karena keseluruhan proses berlangsung secara otomatis. Data yang diperoleh merupakan data yang real time / up to date sehingga mampu memberikan informasi yang terbaru mengenai kondisi ketinggian gelombang laut yang ada di suatu perairan

\section{Saran}

Beberapa saran dalam rangka pengembangan penelitian ke depan dan optimalisasi penelitian yang telah dilaksanakan, yaitu:

a. Jangkauan maksimal pengiriman data yang dapat dilakukan menggunakan alat yang telah dibuat adalah $1 \mathrm{~km}$ di ruangan terbuka. Untuk memperoleh jangkauan yang lebih jauh, perlu dicari system radio link yang lebih baik spesifikasinya.

b. Kemampuan catu daya aki yang terbatas apabila digunakan terus-menerus (kurang lebih 1.5 bulan), sehingga perlu disiapkan aki cadangan ataupun sumber catu daya yang lain

c. Selain untuk mendapatkan data gelombang permukaan laut secara real time dan up to date, alat ukur gelombang permukaan laut hasil penelitian rancang bangun ini, dapat pula digunakan sebagai prototype alat untuk perencanaan dermaga pangkalan TNI AL, perencanaan bangunan break water pada pelabuhan, perencanaan bangunan off shore / bangunan lepas pantai

\section{DAFTAR PUSTAKA}

[1] A. Adityayuda. Pengukuran Faktor Koreksi Jarak Pada Instrumen Motiwali. Skripsi. Bogor: Institut Pertanian. 2012.

[2] Afniza. Pembuatan Alat Ukur Kadar Alkohol Pada Minuman Menggunakan Sensor TGS822 Berbasis Mikrokontroler AVR ATMega8535. Skripsi. Medan: Universitas Sumatera Utara. 2010. [3] BAKOSURTANAL. Prediksi Pasang Surut 2014. Bidang Medan Gayaberat dan Pasang Surut, Pusat Geodesi dan Geodinamika, Badan Koordinasi Survei dan Pemetaan Nasional Cibinong, Bogor. 2014. 
[4] M. Fatoni, Harianto dan M.C. Wibowo. Rancang Bangun Absensi Mahasiswa Menggunakan RFID Dengan Komunikasi Terpusat. Jcones. 2013; 2(1): 43-50.

[5] Garisson. Aplied Oceanography. New York: John Willey and Sons, Inc. 1993.

[6] M.G. Gross. Oceanography: A View of Earth. New Jersey: Prentice Hall, Inc. Englewood Cliff.1990.

[7] F. Irawan. Rancang Bangun Instrumen Pengukur Gelombang Laut Berdasarkan Sistem Pelampung. Skripsi. Pontianak: Universitas Tanjungpura. 2010.

[8] F. Johansyah, Sudjadi dan R. Arianto. Kontrol Automatis Fin Stabilizer Pada Kapal Perang Tipe FPB-57 Dengan Berbasiskan Mikrokontroler MC68HC11F1. Skripsi. Semarang: Universitas Diponegoro. 2011.

[9] E. Nurwansyah, A. Andy dan W. Siang. MP3 Player Dengan RFID. Skripsi. Jakarta: Universitas Bina Nusantara, Jakarta. 2009.

[10] Pond dan Pickard. Introductory to Dynamic Oceanography. Oxford: Pergamon Press. 1978.

[11] I. Purnama, I. Rancang Bangun Alat Pengukur Laju Kendaraan Berbasis Mikrokontroler ATMega8. Skripsi. Bandung: Universitas Komputer Indonesia. 2011.

[12] T.A. Tanto. Kinerja OTT PS 1 Sebagai Alat Pengukur Pasang Surut Air Laut Di Muara Binuangeun, Provinsi Banten. Skripsi. Bogor: Institut Pertanian Bogor. 2009.

[13] Z. Yusuf. Alat Pengaman Jarak Antar Kendaraan Guna Mengurangi Angka Kecelakaan Di Jalan Raya. Skripsi. Malang: Universitas Brawijaya. 2009. 